\title{
Characterization of Diversity of Bradyrhizobia on Cowpea in Iraq Reveals Unusual Strain Characteristics
}

\author{
Suad A. Al-Saedi ${ }^{1 \dagger}$, Naoufal Lakhssassi ${ }^{2 \dagger}$, My Abdelmajid Kassem ${ }^{3}$, Ibrahim B. Razaq ${ }^{1 \dagger}$, and \\ Khalid Meksem ${ }^{2 *}$
}

${ }^{1}$ Agricultural Researcher Directorate, Ministry of Science and Technology, Baghdad, Iraq; ${ }^{2}$ Department of Plant, Soil, and Agricultural Systems, Southern Illinois University, Carbondale, IL 62901, USA; ${ }^{3}$ Plant Genomics and Biotechnology Laboratory, Department of Biological Sciences, Fayetteville State University, Fayetteville, NC 28301-4298, USA.

Received: April 23, 2017 / Accepted: May 7, 2017

\section{Abstract}

Rhizobium-legume symbiosis is considered as one of the most well established symbiotic nitrogen fixing system for agronomic studies. Association between legumes and rhizobia results in the formation of root nodules where symbiotic nitrogen fixation occurs. The current study aimed to authenticate 110 isolates from 20 sites belonging to 10 governorates in Iraq, tested their capacity of nodulation with cowpea and classified them depending on the phenotype and genotype presented by sequence analysis of 165 rRNA. To fulfill these goals, many approaches have been implemented such as Authentication Tests, Bromothymol Blue Reaction, Colony Size and Morphology, Antibiotic Test, Sequencing of 165 rRNA and Phylogenetic analysis. This study provides an easy way to classify the Bradyrhizobia sp. strains by genotype analysis depending on the phenotypes (i.e. motility and colony size) by sample preservation and high quality DNA isolation from environmental soil samples followed by 165 rRNA sequencing. This molecular technique has demonstrated the usefulness of these methods, easy technologies, and their applications to microbiome analysis and environmental science. Interestingly, a group of Bradyrhizobia identified in the current study was able to secrete acidic products before switching and starting to secrete alkali products after 1,2 and 3 days. This is an unusual phenotype observed within rhizobia strains.

Keywords: 16S rRNA, Nitrogen, Symbiosis, Locations, Strains.

\section{Introduction}

Crop yields are linked to the use of soil or foliar fertilizers that are applied to supply one or more essential nutrients that support plant growth and production (Stewart et al., 2005). Many reports estimate that 30 to $50 \%$ of crop yields are attributed to natural or synthetic commercial fertilizers (Gowariker et al., 2009; Stewart et al., 2005). There are 14 essential elements for plant growth and development. Nitrogen (N), Phosphorus (P) and Potassium $(K)$ are the three essential elements needed in large quantity by plants, which are usually known as Macroelements (Salisbury and Ross, 1985). Not all soils are rich in NPK and thus nutrients must be supplied through fertilizers (Dittmar et al., 2009). In fact, these three elements must be added to arable soils to secure the sufficiency level of each for optimum crop yield. However, most farmers worldwide, due to high costs and environmental concerns, limit the use of synthetic fertilizers. Although much of the nitrogen is removed when protein-rich grains or hay are harvested, significant amounts can remain in the soil for future crops (Bisen et al., 2012). This is especially important when nitrogen fertilizer is not used, such as in crop rotation schemes used in less industrialized countries. Nitrogen is the most commonly deficient nutrient in many soils around the world; therefore, it is the most commonly supplied plant nutrient. During the last two decades, many studies focused on the widespread applications of natural nitrogen suppliers such as nitrogen-fixing Rhizobia sp. (Abaidoo et al., 2000; Shahzad et al., 2012; Steenkamp et al., 2008; Abdulameer, 2010; Martyniuk et al., 2013).

\footnotetext{
* Corresponding author: meksem@siu.edu.

${ }^{\dagger}$ These authors contributed equally to this work.
}

ATLOS Publishing, LP
This is an Open Access article distributed under the terms of the Creative Commons Attribution License (http://creativecommons.org/licenses/by/3.0/), which permits unrestricted use, distribution, and reproduction in any medium, provided the original work is properly cited. 
Rhizobia sp. is soil bacteria that fix nitrogen (diazotrophs) after establishing inside root nodules of legumes (Fabaceae) in a very well-known process called biological nitrogen fixation (BNF). Rhizobia require a plant host and cannot independently fix nitrogen. The Rhizobium-legume symbiosis is one of the most prominent beneficial plant-microbe interactions (González and Gonzalez-López, 2013). BNF has received high attention because of the central role it plays in the maintenance of soil fertility (Sprent and Sprent, 1990; Chemining'wa et al., 2011). Legumes have the potential to contribute to soil nitrogen and increase yields of subsequent or associated non-legume crops through symbiotic nitrogen fixation (Brockwell et al., 1995).

Cowpea (Vigna unguiculata L. Walp.) is one of the main products of family farming in semi-arid regions such as Iraq and is of considerable importance as a protein source for low-income populations of rural areas. It is well known that cowpea is relatively resistant to salinity and drought stress (Eaglesham et al., 1992). Cowpea Rhizobia were first classified as a heterogeneous group of slow-growing rhizobia that nodulates promiscuous tropical and subtropical legume species known as 'cowpea cross-inoculation group' (Allen and Allen, 1981). Furthermore, Rhizobia, representing the 'cowpea group' Cowpea Rhizobia (Bradyrhizobium spp.), are usually slow-growing bacteria of the genus Bradyrhizobium belonging to the order Rhizobiales of the Alphaproteobacteria class (Garrity et al., 2005; Jordan, 1982; Kuykendall, 2005a,b). Bradyrhizobium species are Gram-negative bacilli (rod shaped) with a single subpolar or polar flagellum. Many changes in rhizobia taxonomy have occurred during the last decade due to an increase of available phenetic and genetic information about this group of bacteria (Silva et al., 2012). Knowledge of the diversity of rhizobia is of paramount importance as it is a source of genetic resources for selection of strains adapted to different conditions. Currently, the system of microbial taxonomy addresses a joint analysis of morphological, physiological and different molecular tools. Statistical methods are used to evaluate the differences and similarities among microorganisms, providing quantitative measures of similarities among microorganisms. However, rhizobia taxonomy has been changed in recent years due to the use of molecular tools allowing for the identification of new groups of bacteria capable of nodulation and nitrogen fixation in legumes (Chen et al., 2005). In this study, a total of 110 strains isolated from 20 sites belonging to 10 governorates in Iraq were tested for their ability to fix nitrogen and to symbiotically interact with the cowpea as a plant host. Next, we focused on bacterial nodulation by testing new rhizobia isolates from the 20 sites belonging to the most important cowpea production area in Iraq. Interestingly, the 60 rhizobia strains were genetically identified and classified by sequencing the $16 \mathrm{~S}$ rRNA gene. The $16 \mathrm{~S}$ rRNA gene is a highly conserved component of the transcriptional machinery of all DNA-based life forms and thus is highly suited as a target gene for sequencing DNA in samples containing up to thousands of different species.

\section{Material and Methods}

\section{Bacterial Isolate}

One hundred and ten bacteria isolates were obtained from cowpea root nodules in 20 different field sites in 10 governorates of Iraq, belonging to the most important cowpea production areas in the country. These are namely: Al Basrah, Dhi-Qar, Misan, Wasit, Babil, Al Anbar, Baghdad, Salahudein, Suleimanyah, and Ninevah. Nodules were surface sterilized by immersing in $95 \% \mathrm{v} / \mathrm{v}$ ethanol for $10 \mathrm{sec}$. followed by $30 \% \mathrm{v} / \mathrm{v}$ solution of sodium hypochlorite for $4 \mathrm{~min}$ and then rinsed with sterile distilled water. They were then placed in $3 \% \mathrm{v} / \mathrm{v}$ hydrogen peroxide for $1 \mathrm{~min}$, followed by rinsing five times in sterile water. The sterilized nodules were crushed in a large drop of sterile water in a petri dish. The nodule suspension was next streak inoculated on yeast mannitol agar (YMA) (Somasegran and Hoben, 1994) and incubated at $28^{\circ} \mathrm{C}$ for 5 days. Single colonies were selected and streaked onto YMA slant and kept at $4^{\circ} \mathrm{C}$ for short-term storage with sub culturing every 4 months. Long-term storage was carried out by storing the culture broth in $10 \%$ glycerol at $-80^{\circ} \mathrm{C}$.

\section{Authentication Tests}

All 110 bacterial strains were authenticated in order to determine if they were cowpea rhizobia by observing nodule formation on cowpea roots grown in autoclaved sandy soil. Sterilized seeds of cowpea cultivars were inoculated with different bacteria strains. Non-inoculated controls were used to check for cross-contamination.

\section{Nodulation Assay of the Cowpea Plants}

Cowpea plants were grown on autoclaved sandy and organic soil (50:50) and watered as needed. Sixty rhizobium strains were grown in YMA medium for 5 days at $28^{\circ} \mathrm{C}$ until reaching the exponential growth phase. Bacterial inoculation was done at the time of sowing (10\% volume by seed weight). Inoculated plants were grown in the greenhouse under $27^{\circ} \mathrm{C}, 70 \%$ humidity, and 16-hour artificially supplemented light conditions.

\section{Bromothymol Blue Reaction}

All authenticated cowpea rhizobia cells were streaked onto agar plates containing YM medium with Bromothymol blue at $25 \mu \mathrm{l} / \mathrm{ml}$ final concentration. Then, the plates were incubated at $28^{\circ} \mathrm{C}$. The authenticity of each strain was detected during the 10 day incubation period with observation for color of the indicator dye on the plates (Somasegaran and Hoben, 1994). Fast growing rhizobia changed color of the indicator dye to yellow while slow growing rhizobia turned the indicator dye to blue.

\section{Colony Size and Morphology}

Colony size and morphology were measured by incubating single cells onto the center of agar plates containing $Y M$ me- 
dium. The plates were incubated at $28^{\circ} \mathrm{C}$ for 10 days with morphology observations of movement, convex, flat, etc. The size of the colonies was also measured at the end of the 10-day incubation period.

\section{Antibiotic Test}

Antibiotic tests were conducted by spreading bacteria on petri dishes containing Mueller-Hinton agar and testing two different antibiotic discs. The discs were equidistant from the others to avoid overlapping zones of inhibition. The antibiotics discs tested were Spectinomycin and Streptomycin at $100 \mu \mathrm{g}$ and 300 $\mu \mathrm{g}$ concentrations, respectively. The plates were incubated at $28^{\circ} \mathrm{C}$. The presence or absence of an inhibition zone was noted, indicating susceptibility, resistance, or intermediate resistance.

\section{DNA Isolation}

In order to extract bacterial DNA, the bacteria isolates were incubated into $Y M$ broth in a $15 \mathrm{ml}$ sterile tube and incubated under shaking conditions at $200 \mathrm{rpm}, 28^{\circ} \mathrm{C}$ for 5 days. Cells were harvested by centrifugation at $13.2 \times 1000 \mathrm{rpm}$ for 10 min then washed once with $0.85 \% \mathrm{NaCl}$ solution to eliminate extracellular polysaccharides before chromosomal DNA isolation. Bacterial DNA was obtained using Wizard Genomic DNA purification kit from Promega.

\section{Polymerase Chain Reaction (PCR) Amplification of the 16S rRNA Gene}

Genomic DNA from each isolate was amplified using the primer fDI (5'- AGAGTTTGATCCTGGCTCAG - 3') and rD1 (5`- AAGGAGGTGATCCAGCC - 3') in order to amplify the $16 S$ rRNA as described by Weisburg et al. (1991). The selected primers were derived from conserved regions of the 16S rRNA gene and amplified nearly $1500 \mathrm{bp}$ of full-length $16 \mathrm{~S} r R N A$ gene (Weisburg et al. 1991). PCR amplifications were carried out in total reaction volumes of $25 \mu \mathrm{l}$ containing $2.0 \mathrm{mmol} / \mathrm{L}$ $\mathrm{MgCl} 2,200 \mu \mathrm{mol} / \mathrm{L}$ of dNTPs, $1 \mu \mathrm{mol} / \mathrm{L}$ of each primer, $30 \mathrm{ng}$ of genomic DNA and 1.5 U OF Pfu DNA polymerase (Agilent Technologies). The temperature profile was as follows: an initial denaturation step at $95^{\circ} \mathrm{C}$ for $3 \mathrm{~min}, 35$ cycles of denaturation at $94^{\circ} \mathrm{C}$ for $30 \mathrm{sec}$; then annealing at $51^{\circ} \mathrm{C}$ for $1 \mathrm{~min}$ and extension at $72^{\circ} \mathrm{C}$ for $2 \mathrm{~min}$ with a final extension at $72^{\circ} \mathrm{C}$ for $7 \mathrm{~min}$

\section{Sequencing of 165 rRNA}

Products of amplification belonging to approximately 60 strains were purified with QIA quick PCR purification kit (from QIAGEN) prior sequencing and then sequenced at GeneWiz

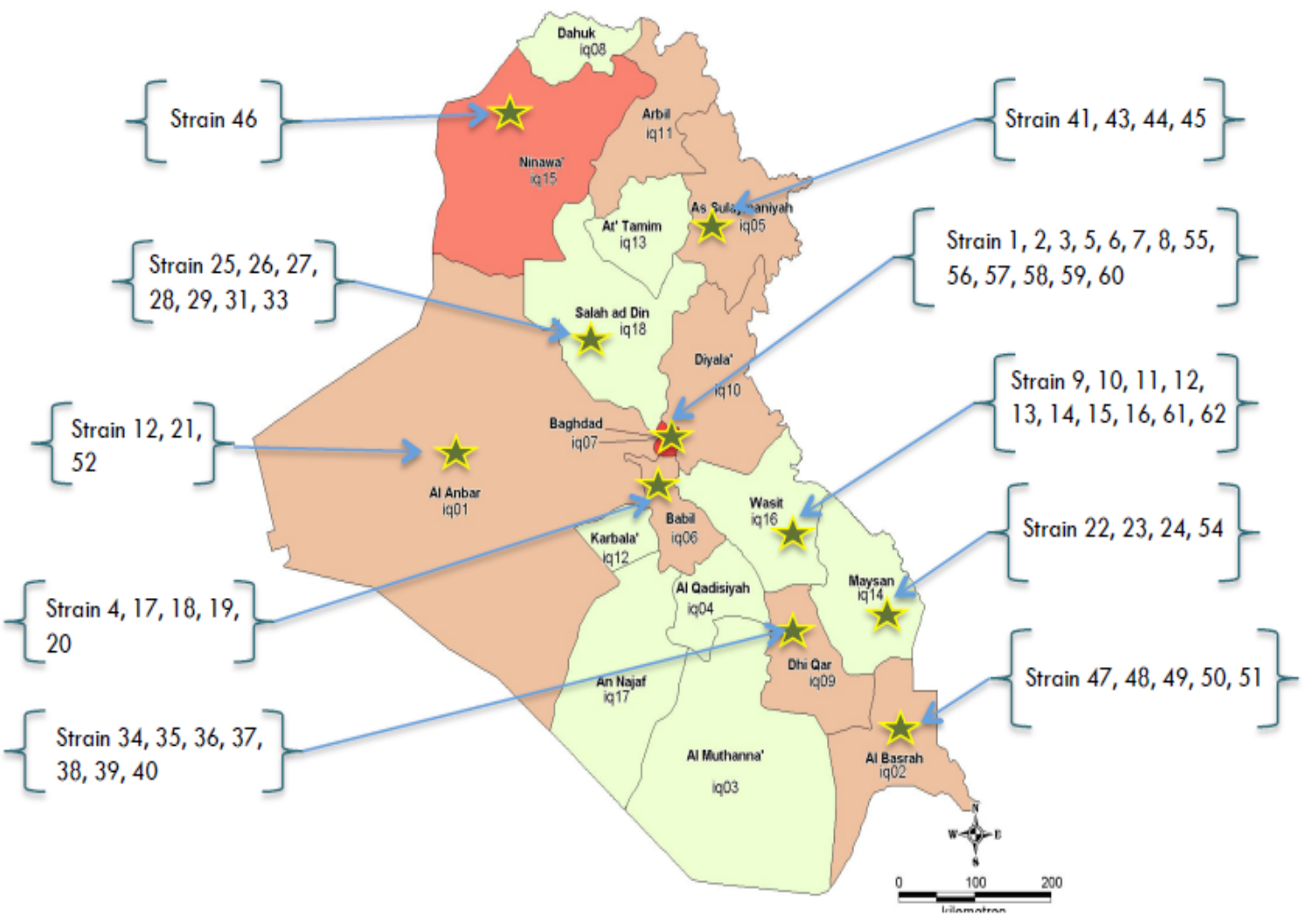

Fig. 1. Geographic distribution of the rhizobia bacterial collection sites in Iraq. Sixty bacteria isolates were obtained from cowpea root nodules of 20 locations from different field sites in 10 governorates in Iraq, belonging to the most important cowpea production area in Iraq (Basrah, Dhi-Qar, Misan, Wasit, Babil, Al Anbar, Baghdad, Salahudein, Suleimanyah, and Ninevah). 
Company, USA, using the primers fDl and rD1. The $16 \mathrm{~S}$ rRNA sequences were first analyzed with Seqman-DNA star Lasergene software; then, the closely related sequences found were analyzed by Culstal W program.

\section{Phylogenetic Analysis and Genomic Structure}

Multiple sequence alignments were performed using the MEGA4 software package and the Clustal-W algorithm. An unrooted phylogenetic tree was calculated with the neighbourjoining method (Saitou and Nei, 1987), and tree topology robustness was tested by bootstrap analysis of 5,000 replicates. Alignment analysis of the $16 \mathrm{~S}$ rRNA sequenced genes from the different rhizobia strains, in addition to the reference $16 \mathrm{~S}$ rRNA sequences were obtained using MegAlign 4 software. All parameter values corresponded to default definitions.

\section{Results}

\section{Authentication Test}

In this study, a total of 110 strains isolated from 20 sites belonging to 10 governorates in Iraq (Fig. 1) were tested to their ability to form nodules. From the 110 bacteria isolated, we authenticated a total number of 60 isolates that re-nodulated their original host cowpea confirming their symbiotic status (Table 1).

Table 1. Phenotypic data of the Sixty cowpea rhizobia. Second column present the nodule number, third and fourth column show the colony size after 5 and 10 day of growth, last columns present antibiotic discs tested; Spectinomycin and Streptomycin at $100 \mathrm{mg}$ and $300 \mathrm{mg}$ concentrations, respectively. $S=$ susceptibility, $R=$ resistance or $I=$ Intermediate resistance. Red signs present the five cowpea rhizobia found to resist to both antibiotics.

\begin{tabular}{|c|c|c|c|c|c|c|c|c|c|}
\hline \multirow{3}{*}{ Strain ID } & \multirow{3}{*}{$\begin{array}{l}\text { Nodule number } \\
\text { with Cowpea }\end{array}$} & \multirow{2}{*}{\multicolumn{2}{|c|}{ Colony size (mm) }} & \multicolumn{6}{|c|}{ Antibiotic Test } \\
\hline & & & & \multicolumn{3}{|c|}{ Spectinomycin } & \multicolumn{3}{|c|}{ Streptomycin } \\
\hline & & After 5 days & After 10 days & $\mathrm{s}$ & $\mathrm{I}$ & $R$ & $\mathrm{~s}$ & 1 & $\mathrm{R}$ \\
\hline S1 & 50 & 35 & 85 & + & & & + & & \\
\hline S2 & 20 & 85 & 85 & & + & & + & & \\
\hline S3 & 55 & 85 & 85 & & + & & + & & \\
\hline S4 & 12 & 12 & 20 & + & & & + & & \\
\hline S5 & 5 & 85 & 85 & & + & & + & & \\
\hline S6 & 25 & 85 & 85 & + & & & + & & \\
\hline S7 & 4 & 12 & 20 & + & & & + & & \\
\hline 58 & 30 & 10 & 15 & + & & & + & & \\
\hline s9 & 35 & 25 & 85 & & + & & + & & \\
\hline S10 & 7 & 12 & 20 & & + & & + & & \\
\hline S11 & 10 & 8 & 15 & & & + & + & & \\
\hline S12 & 25 & 20 & 55 & & & + & + & & \\
\hline S13 & 2 & 10 & 15 & & + & & + & & \\
\hline S14 & 17 & 10 & 20 & & & + & + & & \\
\hline S15 & 29 & 9 & 15 & & + & & + & & \\
\hline S16 & 7 & 19 & 85 & & & + & + & & \\
\hline S17 & 29 & 10 & 22 & & & + & + & & \\
\hline S18 & 7 & 10 & 20 & . & + & & + & & \\
\hline S19 & 2 & 12 & 23 & + & & & + & & \\
\hline S20 & 3 & 12 & 24 & & + & ( & + & & \\
\hline S21 & 18 & 9 & 15 & & & + & + & & \\
\hline S22 & 6 & 10 & 15 & 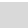 & + & & + & & \\
\hline S23 & 6 & 19 & 24 & & + & & + & & \\
\hline S24 & 7 & 18 & 25 & 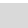 & + & & + & & \\
\hline S25 & 5 & 16 & 25 & + & & & + & & \\
\hline S26 & 25 & 10 & 20 & + & & & + & & \\
\hline S27 & 15 & 75 & 85 & + & & & + & & \\
\hline S28 & 10 & 75 & 85 & + & & - & + & & \\
\hline S29 & 3 & 70 & 85 & & + & & + & & \\
\hline S31 & 10 & 12 & 24 & & & + & 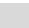 & & + \\
\hline S32 & 6 & 50 & 85 & & & + & + & & \\
\hline S33 & 7 & 50 & 85 & & & + & + & & \\
\hline S34 & 4 & 5 & 10 & 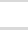 & & + & + & & \\
\hline S35 & 6 & 9 & 16 & & & + & & & + \\
\hline S36 & 4 & 8 & 10 & + & & & + & & \\
\hline S37 & 2 & 10 & 20 & & + & 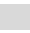 & + & & \\
\hline S38 & 13 & 25 & 85 & & & + & + & & \\
\hline S39 & 10 & 85 & 85 & & & + & + & & \\
\hline S40 & 2 & 10 & 17 & + & & & + & & \\
\hline S41 & 2 & 7 & 10 & + & & & + & & \\
\hline S43 & 7 & 13 & 20 & & + & & + & & \\
\hline S44 & 3 & 8 & 12 & + & & & + & & \\
\hline S45 & 3 & 19 & 26 & & & + & + & & \\
\hline S46 & 2 & 20 & 27 & & + & & + & & \\
\hline S47 & 89 & 85 & 85 & & & + & + & & \\
\hline S48 & 21 & 5 & 10 & & + & & + & & \\
\hline S49 & 89 & 12 & 20 & & & + & + & & \\
\hline S50 & 89 & 10 & 20 & & & + & + & & \\
\hline S51 & 78 & 85 & 85 & & & + & & & + \\
\hline S52 & 3 & 20 & 39 & & + & & + & & \\
\hline S54 & 16 & 85 & 85 & & & + & + & & \\
\hline S55 & 3 & 9 & 20 & & & + & + & & \\
\hline S56 & 2 & 9 & 15 & & & + & + & & \\
\hline S57 & 7 & 10 & 15 & & + & & + & & \\
\hline S58 & 4 & 17 & 85 & & & + & + & & \\
\hline S59 & 19 & 12 & 20 & & + & & + & & \\
\hline $\mathrm{S} 60$ & 1 & 55 & 85 & & & + & + & & \\
\hline S61 & 5 & 85 & 85 & & & + & & & + \\
\hline $\mathrm{S} 62$ & 2 & 12 & 20 & + & & & + & & \\
\hline S63 & 10 & 18 & 28 & & & + & & & + \\
\hline
\end{tabular}




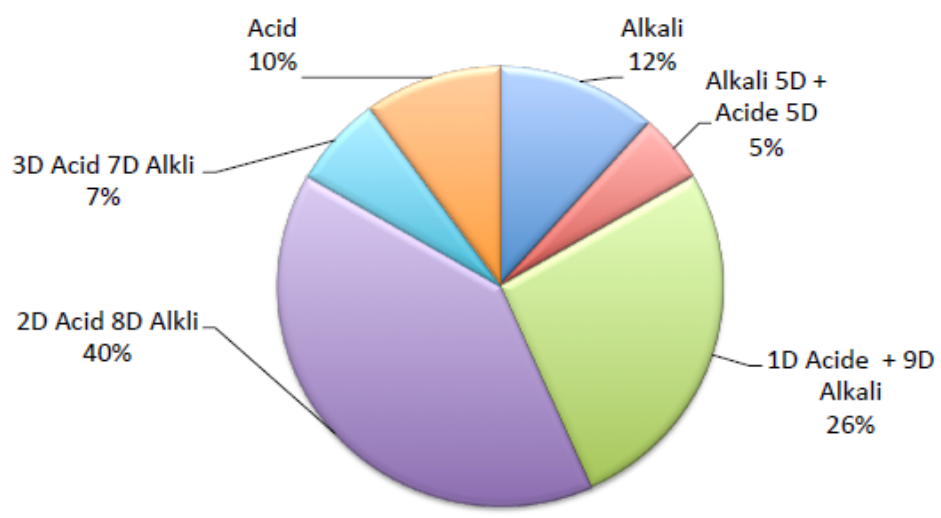

Alkali products after 5- and 10 days incubation (slow growing Bradyrhizobium).

Acidic products after 5- and 10days incubation (fast growing Bradyrhizobium).

Alkali products after 5 days incubation then switch to acidic products for another 5 days incubation (slow growing Bradyrhizobium).

Acidic products the first day before starting to secrete alkali products after the second day (slow growing Bradyrhizobium).

Acidic products the first 2 days before starting to secrete alkali productsafter the third day (slow growing Bradyrhizobium).

- Acidic products the first 3 days before starting to secrete alkali products after the fourth day (slow growing Bradyrhizobium).

Fig. 2. Reaction type of the sixty cowpea rhizobia with Bromothymol blue. The authenticity of each strain was detected during 10 days incubation period, with observation for color of the indicator dye on the plates. Fast growing rhizobia changed color of indicator dye to yellow while slow growing rhizobia turned the indicator dye to blue.

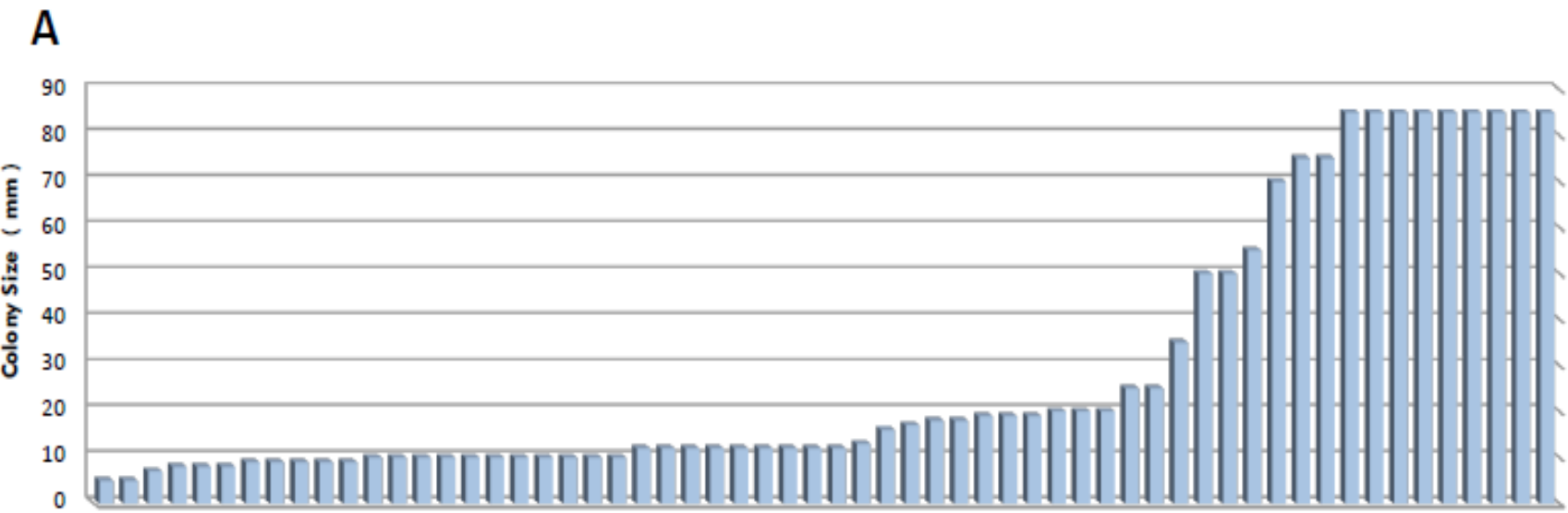

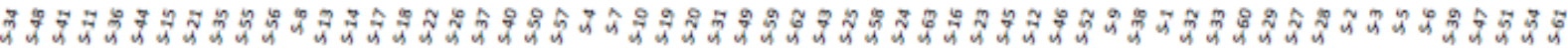

B

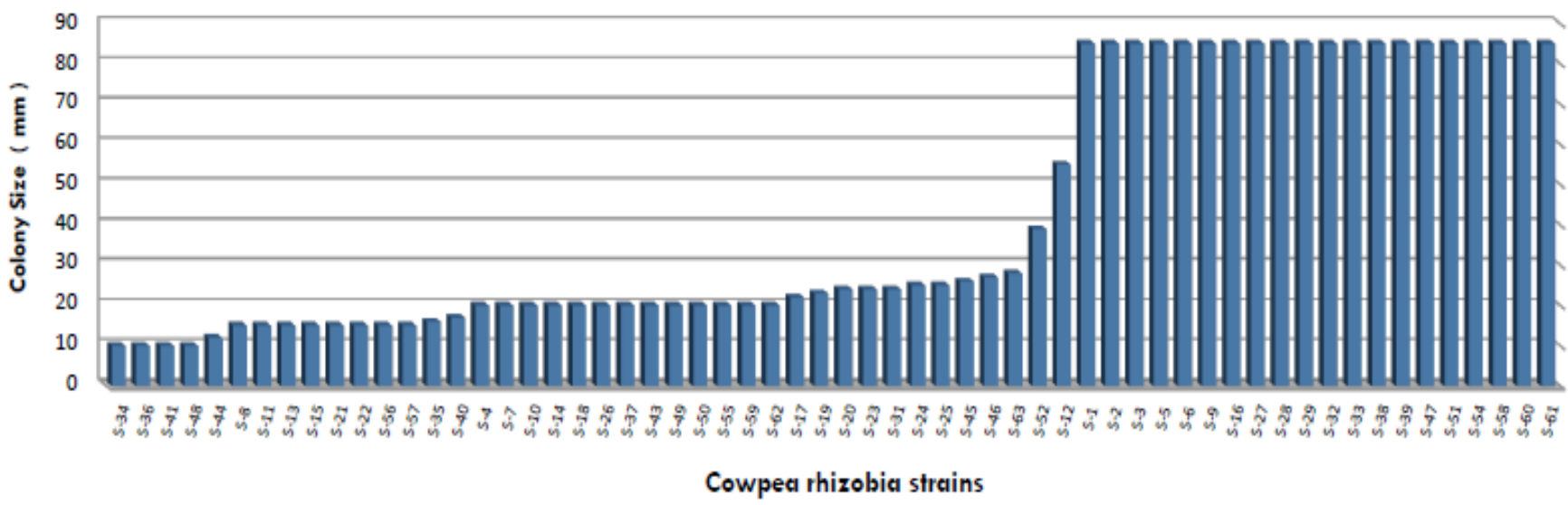

Fig. 3. Colony size of the sixty cowpea rhizobia strains after 5 days (A) and 10 days (B) growth. 


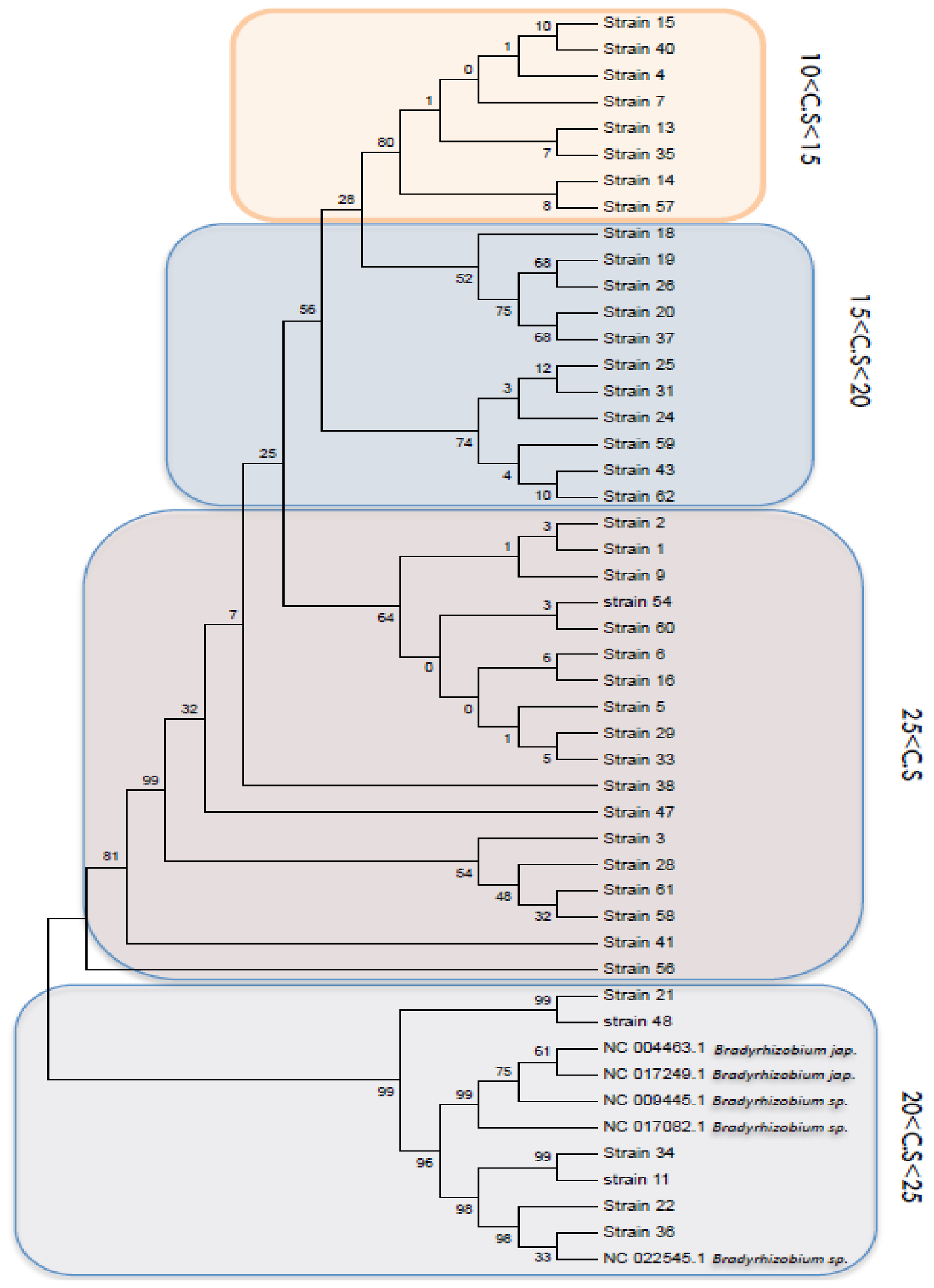

Fig. 4. Neighbour Joining (NJ) tree showing the phylogenetic relatedness of 16 RNA sequences for 43 cowpea rhizobia associated with the colony size (C.S) and cell movement. The phylogenetic tree was generated using ClustalW and Mega 4 softwares, and boostrap values are shown using 5,000 replicates. 
The authentication test showed that 38 (63.3\%) cowpea rhizobia presented a nodule number less than 10, 8 (13.3\%) strains presented between 10 and 20 nodules, $6(10 \%)$ strains presented between 20 and 30 nodules, $3(5 \%)$ strains presented between 30 and 70 nodules, and 4 super-nodulating (6.66\%) strains (S47, S49, S50 and S51) presented between 70 and 90 nodules per plant. Surprisingly, the four strains from the last super-nodulating group belong to Al-Basrah governorate. This result may be related to the physical composition of the soil in this area, which differs from the rest of the 10 governorates in Iraq. Furthermore, all 60 strains were chosen for genotypic characterization (16S rRNA target sequencing) and phenotypic analysis including colony size, morphology, bromothymol blue reaction, and antibiotic resistance test.

\section{Phenomic Analysis of the Rhizobia Strains}

The bromothymol blue technique is used in bacteriology as a $\mathrm{pH}$ indicator in the agar. It changes to yellow in case of acid production during fermentation of lactose or changes to deep blue in case of alkalinization. Lactose-positive bacteria build yellow media. However, bacteria that decarboxylate L-Cystine cause an alkaline reaction and build deep blue media. This colorant is used essentially in order to classify rhizobia, especially Bradyrhizobium (Alkaline reaction) from rhizobium (Acidic reaction) strains. The reaction of the 60 cowpea rhizobia colonies on bromothymol blue (BTB) agar plates revealed two major types of reactions. In the first type of reaction, cells of 6 cowpea rhizobia were found to secrete acidic product during 10 days incubation. Surprisingly, 3 strains were able to secrete alkali product during the first 5 days before switching and starting the secretion of acidic product in the last 5 days during the 10 days incubation (Fig. 2). Furthermore, most cells were in the second type of BTB reaction and were found to secrete alkali product. This second type was divided into 4 types of reactions. Seven cowpea rhizobia belong to a group that secreted alkali product during the 10 days incubation. Surprisingly, the second, third and fourth groups were able to secrete acidic products during the first days before starting to secrete alkali products after 1 (16 strains), 2 (24 strains) and 3 (4 strains) days. This is an unusual phenotype observed within rhizobia strains (Fig. 2).

Furthermore, the 60-cowpea rhizobia colonies were regrouped in 4 groups depending on their capability to grow (colony size) and capacity to invade the whole petri dish (motility). The first group of the four-regrouped colony contained 13 cowpea rhizobia presenting size of colonies between (10-15) mm, of which 8 bacteria were flat in shape and 5 were convex. The second group containing 15 bacteria showed sizes between 15 and $20 \mathrm{~mm}$, of which 6 were flat in shape and 9 were convex. The third group with 7 bacteria had sizes between 20 and 25 $\mathrm{mm}, 6$ of which were flat in shape and one was convex. Finally, the fourth group with 25 bacteria were able to grow more than $25 \mathrm{~mm}$ until they filled the whole plate during the 10 days of incubation; 20 of them were flat in shape and 5 were convex. Interestingly, all bacteria belonging to groups one, two and three were not motile while all bacteria from group four were motile on agar medium (Fig. 3).
Moreover, all 60 strains were tested in the presence of two kinds of antibiotics: Spectinomycin and Streptomycin. It has been shown that Rhizobia strains can be resistant to Spectinomycin or Streptomycin (Ramírez et al., 1998). However, resistance to both antibiotics can be possible if the strain carries a mutation in its genome (Zelazna-Kowalaska, 1971). The result given in Table 1 showed that 15 cowpea rhizobia were sensitive to spectinomycin and 55 sensitive to streptomycin. However, 25 cowpea rhizobia were resistant only to spectinomycin and 5 resistant only to streptomycin, while 20 cowpea rhizobia had an intermediate resistance to spectinomycin. Interestingly, five cowpea rhizobia (S31, S35, S51, S61 and S63) were found to resist both antibiotics (Table 1) (National Committee for Clinical Laboratory Standards-NCCLS).

\section{Sequencing the 16S rRNA}

The $16 \mathrm{~S}$ rRNA gene sequencing is commonly used for identification, classification, and quantification of microbes within complex biological mixtures such as environmental and gut samples (Schmidt et al., 1991; Ley et al., 2005). The 16S rRNA gene is a highly conserved component of the transcriptional machinery of all DNA-based life forms and thus is highly suited as a target gene for sequencing DNA in samples containing up to thousands of different species (Cox et al., 2013). Conveniently, the $16 \mathrm{~S}$ rRNA gene consists of a conserved and a variable region. While the conserved region makes universal amplification possible, the variable regions allows discrimination between specific different microorganisms (Kolbert and Persing, 1999).

Specific primers have been used in this study to target the conserved regions of $16 \mathrm{~S}$ in order to target conserve and variable regions within the characterized cowpea rhizobia. Phylogenetic analysis of the sequenced $16 S$ rRNA from the 60 rhizobia separated the strains into four clades (Fig. 4). Surprisingly, the phylogenetic tree grouped all the strains based on their ability to grow (colony size) and motility. Thus, Group I contained strains with lower colony size presenting between 10 and 15 $\mathrm{mm}$, Group II strains' size was between 15 and $20 \mathrm{~mm}$, and Group III contained strains able to grow more than $25 \mathrm{~mm}$ until they invade the entire petri dish. Finally the last group IV contained strains with colony sizes varying between 20 and $25 \mathrm{~mm}$.

\section{Discussion}

In this study we characterized a population of 60 Bradyrhizobium found in cowpea nodules, isolated from 20 sites belonging to the most important cowpea production area in Iraq for their ability to form nodules, resist to antibiotics, motility, and study their evolutionary relationships among other Bradyrhizobium species. In order to fulfill these goals, several techniques were employed such as Authentication Test, Bromothymol Blue Reaction, Resistance to antibiotics (Spectinomycin and Streptomycin), phenotypic analysis including colonies size and morphology, and phylogenetic analysis of the sequenced $16 \mathrm{~S}$ rRNA.

When high density inoculum of a rhizobial strain are inoculated into media containing an antibiotic, a few cells may exhibit resistance as a result of spontaneous genetic changes or 
mutations (Josey et al., 1979; Beynon and Josey, 1980; Turco et al., 1986; Kuykendall et al., 1988). Resistance of a rhizobial strain to a particular antibiotic is a useful marker (Schwinghamer and Dudman, 1973; Pankhurst, 1977; Beynon and Josey, 1980; Turco et al., 1986). It is important that antibiotic-resistant strains that are selected for inoculation experiments have not lost their infectiveness (i.e. ability to form nodules) or their effectiveness (i.e. ability to fix nitrogen) in the symbiosis with the host plant (Beynon and Josey, 1980; Kremer and Peterson, 1982; Turco et al., 1986).

Interestingly, from the 60 strains only five cowpea rhizobia (S31, S35, S51, S61 and S63) were found to resist to both antibiotics. It has been shown that rhizobia strains can be resistant to Spectinomycin or Streptomycin (Karanja and Wood, 1988; Ramírez et al., 1998). However, resistance to both of them can be possible only if the strain carries a mutation in its genome (Schwinghamer, 1964; Zelazna-Kowalaska, 1971; Turco et al., 1986). Several studies showed that mutants treated with gamma radiation were able to grow at $50^{\circ} \mathrm{C}$ (Chitchanok et al., 2011) or at temperatures higher than $40^{\circ} \mathrm{C}$ (Hungria et al., 1993), and four of our strains were able to grow at $37^{\circ} \mathrm{C}$ and $50^{\circ} \mathrm{C}$. These strains were probably mutated by the presence of high radiation level in the soil, since several studies showed that certain bacterial strains are sensitive to nuclear radiation (Makarova et al., 2001).

Four strains, (S47, S49, S50, and S51) presenting $6.66 \%$ of the authenticated rhizobium were super-nodulated, presenting between 70 and 90 nodules per plant, and belong to Al-Basrah governorate. This result may be related to the physical composition of the soil in this area, which differs from the rest of the 10 governorates in Iraq. Al-Basrah is located on the Shatt-Al-Arab waterway, downstream of which is the Arabian Gulf. The city is penetrated by a complex network of canals and streams vital for irrigation and other agricultural use, which makes it one of the most fertile regions for agriculture, located at the juncture of two famous rivers in Iraq, Al forat and Dijlah. The sediments of Al-Basrah soils are mainly silt clay in texture and silt clay loam with subordinate amount of sand. Al-Basrah soils are characterized by their wide spectrum of mineralogical composition, non-clay minerals (calcite, dolomite, quartz, halite, gypsum, and feldspar), clay minerals (kaolinite, Illite, montmorillonite, palygorskite, chlorite, and mixed-layred clay minerals), and heavy mineral (opaque, pyroxene, hornblende, chlorite, biotite, epidote, garnet, kyanite, staurolite, celestite, zircon, and tourmaline). The organic matter content has widely ranged in present soils; its amount depends upon the intensity of vegetation cover. The detrital supply of clastic materials controls the concentration of silica and aluminum. Plant nutrition controls the concentration of $\mathrm{Fe}$ and $\mathrm{K}$. Climatic conditions and hydrogeological setting controls the accumulation of $\mathrm{Na}, \mathrm{Ca}$ and $\mathrm{Mg}$ in Basrah soils. The values of major elements in Al-Basrah saline soils survive seasonal fluctuations because of precipitation and dissolution alternative processes (Al-Marsoumi and Al-Jabbri, 2007).

Moreover, sequence analysis of $16 \mathrm{~S}$ rRNA has also been used frequently for microbial taxonomy, and it is a powerful and accurate method for determining inter- and intra-specific relationships (Stackebrandt and Goebel, 1994; Janda and Ab- bott, 2007; Wang et al., 2007; Kim et al., 2012). On the basis of $16 \mathrm{~S}$ rRNA sequences, six of the strains we isolated from cowpea are closely related to both $B$. japonicum and Rhizobium species (representatives to group IV), which regrouped strains presenting colony sizes between 20 and $25 \mathrm{~mm}$ without motility. Phylogenetic analysis showed that all the rest of the 54 strains descended from the common ancestral copy in the group IV. Those 54 descendants evolved into different strains regrouped in 4 different sub-clades or branches. Group I contained strains with lower colony size between 10 and $15 \mathrm{~mm}$, and Group II between 15 and $20 \mathrm{~mm}$ without motility, and Group III contained strains able to grow more than $25 \mathrm{~mm}$ until they invaded the entire petri dish showing a clear motility in the agar. As shown in different studies, phylogenetic analysis supported their descent from a common ancestral copy (Gherbi et al., 2008) and generated a topology consistent with previous legume phylogenies (Wojciechowski et al., 2004). This gave rise to the hypothesis that the evolutionarily recent legume-rhizobia symbiosis reuses some of the molecular mechanisms of the more ancient arbuscular mycorrhiza (AM) symbiosis (Hirsh, 2004). Using this molecular technique, we resolved the cowpea bradyrhizobial diversity of 60 nodulating strains regrouping them into four different genotypes (Fig. 4).

This study provides an easy way to classify the rhizobia strains by genotype analysis depending on the phenotypes observed (i.e. motility and colony size) by sample preservation and high quality DNA isolation from environmental samples such as soil samples and $16 \mathrm{~S}$ rRNA target sequencing. This demonstrated the usefulness of these methods, using easy technologies, and their applications to microbiome analysis and environmental science.

\section{Conflict of Interest}

The authors declare that they have no conflict of interest.

\section{References}

Allen ON and EK Allen (1981) The leguminosae. A source book of characteristics, uses and nodulation. London, UK: Mocmillan.

Al-Marsoumi AMH and MHA Al-Jabbri (2007) Basrah Soils; Geochemical Aspects and Physical Properties-A Review of Basrah Journal of Science(C) 25 (1): 89-103.

Beynon JL and DP Josey (1980) Demonstration of Heterogeneity in a Natural Population of Rhizobium phaseoli using Variation in Intrinsic Antibiotic Resistance. Microbiology 118 (2): 437-442.

Bisen PS, D Mousumi, and GB Prasad (2012) Microbes: Concepts and Applications.

Brockwell J, PJ Bottomley, and JE Thies (1995) Manipulation of rhizobia microflora for improving legume productivity and soil fertility: a critical assessment. Plant Soil 174: 143-180.

Chemining'wa GN, SWM Theuri, and JW Muthomi (2011) Abundance of indigenous Rhizobia nodulating cowpea and common bean in central Kenyan soils. Afr J Hort Sci 5: 92-97.

Chen WM, EK James, JH Chou, SY Sheu, SZ Yang, and JI Sprent (2005)Rhizobia from Mimosa pigra, a newly discovered invasive plant inTaiwan. New Phytologist 168: 661-675.

Chitchanok A, P Rattasaritt, S Suthatip, P Suphaporn, P Nattayana, and 
T Yanee (2011) Improvement of Vitamin B6 Production from Rhizobium sp. 6-1C1 by Random Mutation. KKU Res J 16(8): 911-918.

Cox MJ, WO Cookson, and MF Moffatt (2013) Sequencing the humanmicrobiome in health and disease. Hum Mol Genet 22 (R1): R88-94.

Dittmar H, M Drach, R Vosskamp, ME Trenkel, R Gutser, and G Steffens (2009) Fertilizers, 2. Types. Ullmann's Encyclopedia of Industrial Chemistry, Wiley-VCH, Weinheim. doi:10.1002/14356007. n10_n01.

Eaglesham AR, JA Ayanaba, VR Rama, and DL Eskew (1992) Mineral $\mathrm{N}$ effects on cowpea and soybean crops in a Nigeria soil: Amounts of nitrogen fixed and accrual to the soil. Plant Soil 68: 183-186.

Garrity GM, JA Bell, and T Liburn (2005) Class I. Alphaproteobacteria class. Nov. In Bergey`s Manual of systematic Bacteriology, 2nd end, vol. 2, part C, P. 1. Edited by Brenner DJ, Krieg, NR Staley JT and Garrity. GM New York: springer.

Gherbi H, K Markmann, S Svistoonoff, J Estevan, D Autran, G Giczey, F Auguy, B Péret, L Laplaze, C Franche, M Parniske, and D Bogusz (2008) SymRK defines a common genetic basis for plant root endosymbioses with arbuscular mycorrhiza fungi, rhizobia, and Frankiabacteria. PNAS 105 (12): 4928-4932. doi: 10.1073/ pnas.0710618105.

González MBR and J González-López (2014) Beneficial Plant-microbial Interactions: Ecology and Applications. CRC Press. Taylor \& Francis Group, Boca Raton, FL 33487-2742.

Gowariker V, VN Krishnamurthy, S Gowariker, M Dhanorkar, and K Paranjape (2009) The Fertilizer Encyclopedia. John Wiley \& Sons. ISBN 9780470410349. Online ISBN 9780470431771. doi: $10.1002 / 9780470431771$.

Handbook for Rhizobia: Methods in legume-rhizobium technology. New York: Springer-Verlag. pp. 1-6, 167. ISBN 0-387-94134-7.

Hirsch AM (2004) Plant-Microbe Symbioses: A Continuum from Commensalism to Parasitism. Symbiosis 37: 1-19. The 4th International Symbiosis Congress, August 17-23, 2003, Halifax, Canada.

Hungria M, AA Franco, and JI Sprent (1993) New sources of high-temperature tolerant rhizobia for Phaseolus vulgaris L. Plant and Soil 149 (1): 103-109.

Janda JM and SL Abbott (2007) 16S rRNA Gene Sequencing for Bacterial Identification in the Diagnostic Laboratory: Pluses, Perils, and Pitfalls. J. Clin. Microbiol. 45 (9): 2761-2764.

Jones KM, H Kobayashi, BW Davies, ME Taga, and GC Walker (2007 How rhizobial symbionts invade plants: the Sinorhizobium-Medicago model. Nat Rev Microbiol 5: 619-633.

Jordan DC (1982) Transfer of Rhizobium Japonicum Buchanan 1980 to Bradyrhizobim gen. nov. a genus of slow-growing, root nodule bacteria from leguminous plants. Int J Syst Bacteriol 32:136-139.

Josey DP, JL Beynon, AWB Johnson, and JE Beringer (1979) Strain Identification in Rhizobium Using Intrinsic Antibiotic Resistance. Journal of Applied Microbiology 46: 343-350.

Karanja NK and M Wood (1988) Selecting Rhizobium phaseoli strains for use with beans (Phaseolus vulgaris L.) in Kenya: Tolerance of high temperature and antibiotic resistance. Plant and Soil 112 (1):15-22.

Kim OS, YJ Cho, K Lee, SH Yoon, M Kim, H Na, SC Park, YS Jeon, JH Lee, $\mathrm{H}$ Yi, S Won, and J Chun (2012) Introducing EzTaxon-e: a prokaryotic $16 S$ rRNA gene sequence database with phylotypes that represent uncultured species. International Journal of Systematic and Evolutionary Microbiology 62: 716-721. doi:10.1099/ijs.0.038075-0.

Kolbert CP and DH Persing DH (1999) Ribosomal DNA sequencing as a tool for identification of bacterial pathogens. Current Opinion in Microbiology 2 (3): 299-305.

Kremer RJ and HL Peterson (1982) Nodulation Efficiency of Legume Inoculation as Determined by Intrinsic Antibiotic Resistance. Appl Environ Microbiol 43 (2): 636-642.
Kuykendall LD (2005a) Order VI. Rhizobiales ord. nov. In Bergey`s Manual of systematic Bacteriology, 2nd end, 2, part C, P. 324. Edited by DJ Brenner, NR Krieg, JT Staley, and GM Garrity. Springer, New York.

Kuykendall LD (2005b) Genus I. Bradyrhizobium Jordan 1982, 137vp In Bergey`s Manual of systematic Bacteriology, 2nd end, vol. 2, part C, pp. 438-443. Edited by DJ Brenner, NR Krieg, JT Staley, and GM Garrity. Springer, New York.

Kuykendall LD, MA Roy, JJ O'Neill, and TE Devine (1988) Fatty Acids, Antibiotic Resistance, and Deoxyribonucleic Acid Homology Groups of Bradyrhizobiurn japonicum. International Journal of Systematic and Evolutionary Bacteriology 38 (4): 358-361.

Ley RE, F Bäckhed, P Turnbaugh, CA Lozupone, RD Knight, and Jl Gordon (2005) Obesity alters gut microbial ecology. PNAS 102 (31): $11070-11075$.

Makarova KS, L Aravind, YI Wolf, RL Tatusov, KW Minton, EV Koonin, and MJ Daly (2001) Genome of the Extremely Radiation-Resistant Bacterium Deinococcus radiodurans Viewed from the Perspective of Comparative Genomics. Microbiology and Molecular Biology Reviews 65 (1): 44-79.

Pankhurst CE (1977) Symbiotic effectiveness of antibiotic-resistant mutants of fast- and slow-growing strains of Rhizobium nodulating Lotus species. Canadian Journal of Microbiology 23 (8): 1026-1033.

Ramírez ME, DW Israel, and AG Wollum (1998) Using spontaneous antibiotic-resistant mutants to assess competitiveness of bradyrhizobial inoculants for nodulation of soybean. Canadian Journal of Microbiology 44: 753-758.

Saitou $\mathrm{N}$ and $M$ Nei (1987) The neighbor-joining method: A new method for reconstructing phylogenetic trees. Mol Biol Evol 4: 406-425.

Salisbury FB and CW Ross (1985) plant physiology. Wadsubrth publishing company inc. Ca, USA pp. 96-113.

Schmidt TM, EF Delong, and NR Pace (1991) Analysis of a marine picoplankton community by $16 \mathrm{~S}$ rRNA gene cloning and sequencing. Journal of Bacteriology 173 (14): 4371-4378.

Schwinghamer EA (1964) Association between antibiotic resistance and ineffectiveness in mutant strains of Rhizobium spp. Canadian Journal of Microbiology 10 (2): 221-233.

Schwinghamer EA and WF Dudman (1973) Evaluation of Spectinomycin Resistance as a Marker for Ecological Studies with Rhizobium spp. Journal of Applied Bacteriology 36 (2): 263-272.

Silva FV, JL Simões-Araúio, JP Silva Júnior, GR Xavier, and NG Rumjanek (2012) Genetic diversity of Rhizobia isolates from Amazon soils using cowpea (Vigna unguiculata) as trap plant. Brazilian Journal of Microbiology 43 (2): 682-691.

Somasegaran P and HJ Hoben (1994) Handbook for Rhizobia. Methods in Legume-Rhizobium Technology. Springer - Velag, New York. pp. 332-341.

Sprent Jl and P Sprent (1990) Nitrogen fixing organisums. Pure and applied aspects. Chapman \& Hall, London, United Kingdom.

Stackebrandt E and BM Goebel (1994) Taxonomic Note: A Place for DNA-DNA Reassociation and 16S rRNA Sequence Analysis in the Present Species Definition in Bacteriology. International Journal of Systematic and Evolutionary Bacteriology 44 (4): 846-849.

Stewart WM, DW Dibb, AE Johnston, and TJ Smyth (2005) The Contribution of Commercial Fertilizer Nutrients to Food Production. Agronomy Journal 97: 1-6. doi: 10.2134/agronj2005.0001.

Turco RF, TB Moorman, and DF Bezdicek (1986) Effectiveness and competitiveness of spontaneous antibiotic-resistant mutants of Rhizobium leguminosarum and Rhizobium japonicum. Soil Biology and Biochemistry 18 (3): 259-262.

Wang Q, GM Garrity, JM Tiedje, and JR Cole (2007) Naïve Bayesian Classifier for Rapid Assignment of rRNA Sequences into the New 
Bacterial Taxonomy. Applied and Environmental Microbiology 73 (16): 5261-5267.

Weisburg WG, SM Barns, DA Pelletier, and DJ Lane (1991) 16S ribosomal DNA amplification for phylogenetic study. J Bacteriol 173: 697-703.

Wojciechowski MF, M Lavin, and MJ Sanderson (2004) A phylogeny of legumes (Leguminosae) based on analysis of the plastid matK gene resolves many well-supported subclades within the family. Am J Botany 91 (1 1): 1846-1862.

Zelazna-Kowalaska I (1971) Correlation between streptomycin resistance and infectiveness in Rhizobium trifolii. Plant Soil. Spc. Vol. 6771. 